\title{
How Venture Capital Influences High-tech Enterprises' IPO: External Factors versus Internal Growth
}

\author{
Hui $\mathrm{Wu}^{1}$, Yu Wang ${ }^{2 *}$ \\ ${ }^{1}$ School of Accountancy, Shandong University of Finance and Economics, Jinan, China \\ ${ }^{2}$ Ph.D. Candidate in School of Accountancy, Shandong University of Finance and Economics, No.7366 \\ East Second Ring Road, Jinan, China \\ *Corresponding Author.
}

\begin{abstract}
There is huge potential for China to transform and upgrade its traditional manufacturing sector, and high-tech enterprises in manufacturing industries stand out. This study contributes to the literature on how venture capital affects technology-based Enterprises' IPO by evaluating the characters between the two parties. According to the symmetric information theory, certification theory and enterprise property rights theory, the first round of risk financing enterprises from 2010 to 2019 is taken as a research sample to empirically analyze the impact of venture capital and corporate growth on firm listing events. The results show that the investment experience of venture capital institutions, when matched appropriately to firms' specific growth, will facilitate and accelerate the IPO process. Thus the matching degree between the two are significantly positively related to the company's IPO. Under the premise of low growth of the company, venture capital has a significant impact on the listing of the company. As the growth of the company increases, the impact of venture capital on the listing of the company is gradually reduced. Venture capital institutions with overseas backgrounds are more inclined to promote the IPO of invested international companies. Finally, we discuss the implications based on the results of the empirical analysis, and make suggestions for venture capital institutions and companies.
\end{abstract}

Keywords: Venture capital, enterprise growth, matching degree, enterprises' IPO, manufacturing upgrade

\section{Introduction}

Originated in the United States after the Second World War, venture capital is an investment activity that helps start-ups achieve value appreciation by providing financial and resource support to them. With the deepening of economic globalization and strong growth of domestic demand, China has witnessed a series of business startups in manufacturing industries emerged and upgraded. Venture capital has also gradually become an effective driving force for the growth of enterprises in emerging economies. For enterprises striving for listing, proper introduction of venture capital will not only help enterprises mitigate internal financing constraints and expand business activities, but also gain more market attention and favor of investors. Moreover, the successful initial public offering (IPO) of many emerging companies is closely related to the participation of venture capital behind them.

The literature on venture capital can be traced back to 1996, when the development of venture capital industry in the global capital market matured and successfully promoted the information and biotechnology revolution, making the research on venture capital become a hot spot for scholars. For the venture capital institutions, the successful IPO of the invested companies can not only ensure that it can meet its own financing needs, but also is the primary way for venture capital to obtain considerable returns and realize its investment target through the exit. Therefore, venture capital institutions are motivated to promote the IPO of the invested enterprises, and some of them will even promote the IPO process of the enterprises by signing agreements. In the mature capital market, it is very common for enterprises to finance through venture before listing, and the influence of venture capital institutions on the listing ability of enterprises is gradually increasing.

ISSN: 0010-8189

(C) CONVERTER 2020

Www.converter-magazine.info 
At present, the research in the domain of venture capital mainly focuses on the impact of venture capital on the IPO of invested enterprises after the completion of the event, such as the stock market performance, IPO stock underpricing of enterprises and other aspects. There are relatively few researches on the relationship and impact of venture capital on the listing process of invested enterprises. In this paper, those enterprises that made financing by venture capital from 2010 to 2019 are selected as research samples to empirically test whether and how venture capital plays an major part in the IPO event. The research contributions of this paper lies in: studying venture capital's characteristics and enterprise growth from the perspective of investment institutions and investment events, analyzing the combination mode of venture capital and enterprise, discussing the influence of venture capital on enterprise IPO and the influence mechanism of venture capital on the growth of start-up enterprises from the perspective of financing constraints, and putting forward corresponding suggestions from the perspective of venture capital institutions and firms, providing targeted reference for start-up enterprises to formulate scientific and reasonable financing system.

\section{Literature Review}

In the existing research literature, the research on the relation between venture capital institutions and whether enterprises can successfully achieve IPO mainly focuses on two aspect, one is the selection of investment projects before investment, and the other is the cooperation mechanism with enterprises after investment [1].

\subsection{Selection of venture capital projects}

Venture capital institutions avoid investment risks and uncertainties caused by information asymmetry through careful selection of projects [2]. Scholars in this field have made theoretical and empirical studies on how venture capital institutions screen investment projects from the aspects of enterprise management, financial risks, market risks, entrepreneurs' personal qualities and industry fields. Geographic concentration existed in both venture capital firms and companies can also be significantly related to performance of investment [3]. On the basis of analyzing the influencing factors of venture capital decision-making[4], 15 venture capital decision-making indicators are put forward from three dimensions: management quality, strategic thinking and profit [5,6]. Liu Changyong et al.divided the project decision-making process into four stages, and put forward evaluation indicators such as product innovation, market potential, financial risk and yield of the invested enterprise[7]. Combined with option pricing theory[8], the decision-making of venture capital projects is studied from the perspective of market and investment, and the characteristics of venture capital enterprises, the quality of entrepreneurs themselves [9] and the industry environment are taken as the main evaluation indicators. Based on the analysis of the risk formation mechanism[10], it is conducted that the investment risk of venture capital institutions comes from the risks of the invested enterprises themselves, which are closely related to entrepreneurs[11,12]. The innovation ability of enterprises and the innovation of products are very important for venture capital[13], and venture capital institutions are more inclined to invest in product innovators than product imitators[14]. In venture capital, great attention has been paid to the market environment, project potential and enterprise capability of high-tech projects[15]. Venture capital institutions can quickly market patented technologies and obtain economic benefits after entering[16]. Some scholars believed that venture capital institutions will consider their reputation effect and not invest in enterprises with poor returns [17].

\subsection{Cooperation mechanism between venture capital and enterprises}

According to the previous research results, venture capital institutions have three main functions for invested enterprises: providing financial support, playing the role of certification and supervision, and strengthening valueadded services.

2.2.1Cooperative monetary mechanism between venture

Compared with traditional bank financing, venture capital institutions are more suitable for SMEs' demand for capital to ease corporate financing constraints[18,19]. A study of the current financing situation of SMEs in China

ISSN: 0010-8189

(C) CONVERTER 2020

Www.converter-magazine.info 
reveals that venture capital is the best feasible channel for SMEs' early financing[20]. Wu Chaopeng et al. (2012) believed that besides venture capital provides the necessary funds for enterprise development, but also can effectively prevent the over-investment behavior of enterprises to make the investment behavior tend to be rational[21].

\subsubsection{The role of certification \& supervision}

Venture capital institutions will analyze and evaluate the target enterprises in all aspects before formal capital injection. W.L.Megginson et al. (1998) thought that enterprises with venture capital can go public faster and have lower cost than those without venture capital[22]. Because of the certification role of venture capital, enterprises get more recognition before listing, and venture capital institutions with low shareholding ratio have no effect on IPO premium rate of listed enterprises. However, venture capital institutions with high risk investment ratio can significantly reduce the IPO premium rate of enterprises, and the richer the experience of venture capital institutions, the lower the IPO premium rate of enterprises[23]. The relationship between venture capital institutions and invested entities is more complicated than the common equity relationship and creditor's rights relationship[24]. The higher the shareholding ratio of venture capital institutions, the more obvious the certification role of enterprises [25,26]. At the same time, the closer the relationship between venture capital institutions and enterprises is, the more it can reduce the agency cost of enterprises and the obstacles caused by information asymmetry[27]. G. Lee and R.W. Masulis(2011) believed that in order to avoid the moral hazard after investment, venture capital institutions supervise, motivate and punish the management of enterprises by means of contracts[28], and in enterprises with the participation of venture capital institutions, the board of directors generally provides independent board seats for venture capital institutions [29]. Long Yong et al. (2010) argued that the cooperation mechanism between venture capital institutions and entrepreneurs will affect the management mode of enterprises[30].

\subsubsection{Providing value appreciation services}

At the initial stage of the enterprise's start-up, the business performance of the invested enterprise is positively correlated with the value-added services provided by the venture capital institutions[31,32]. Venture capital institutions can provide value-added services for enterprises[33]. In order to recoup the capital outlay and make a profit as soon as possible, investment institutions will help enterprises grow rapidly through their own resources and experience, and provide enterprises with market channels, daily production management consulting, cash flow quality and total sales analysis, future development investment direction, post-listing supervision and support, etc. [34]. At the same time, the value-added services of venture capital institutions can significantly improve the innovation ability of enterprises[35]. After the introduction of venture capital institutions, the innovation acceptance ability and the ability to transform new technologies and new products of enterprises have been significantly improved[36], and the innovation ability of enterprises has been sustained and stable for a long time[37].

\subsection{Enterprise growth after venture capital}

Venture capital can accelerate the growth of enterprises[38]. The existing research mainly focuses on enterprise system improvement, governance structure, business processes, operational efficiency and future development direction of enterprises.

In the field where venture capital institutions gather, SMEs develop relatively fast[39]. The higher the shareholding ratio of venture capital institutions, the greater the growth of enterprises. Some research suggested that introducing venture capital before IPO can improve profitability and solvency, rather than operation ability and future development of enterprises[40]. Others pointed out that the performance of enterprises after listing has declined to varying degrees, but that of enterprises with venture capital background has declined less than those without venture capital[41]. Some scholars hold that the performance growth of an enterprise depends only on whether the enterprise introduces venture capital, and has nothing to do with the shareholding ratio of venture capital institutions, and that they have only a short-term and temporary impact on the invested enterprise[42]. Others suggest that the quality rather than the experience and network of venture capital has significant influences on the investment performance[43]. Some believed that venture capital could only improve the probability of successful listing, but will not improve the business performance of enterprises[44]. 
In summary, the existing literature mostly analyzes the relationship between venture capital and enterprise development from the perspective of enterprise growth, financing channels, innovation ability and ownership structure, and few studies venture capital and enterprise growth from the perspective of investment institutions and investment events. Raising fund by venture capital is one of the effective ways for enterprises to obtain direct financing, which the effect is closly related in the growth of enterprises and IPO. Therefore, based on the analysis of venture capital and corporate portfolio model, the impact of venture capital on enterprise growth and IPO is discussed in this paper.

\section{Theoretical Analysis and Hypotheses Development}

\subsection{Impact of matching degree between venture capital institutions and enterprises on listing}

In the early stage of enterprise development, banks and other financial institutions generally do not support the financing activities of SMEs in order to ensure the safety of funds, because their production and operation risks are relatively high due to small business volume, insufficient cash flow and unstable external market environment. Venture capital, as a financing channel willing to take high risks and grab high returns, just meets the capital needs of enterprises in seed stage or start-up stage, and has a high motivation[45].

Due to the theory of information asymmetry, venture capital institutions are unable to obtain the listing possibility of each enterprise[46]. Therefore, in order to obtain high returns from the listing of enterprises, they will select the investment objects from the top to the bottom through the ranking of enterprise growth and give priority to the enterprises with high growth. In the meantime, the choice between venture capital institutions and enterprises is two-way. Therefore, the enterprise prefers to choose risk investment institutions with rich investment experience and high industry reputation. Enterprises with high growth potential will introduce venture capital institutions with rich investment experience, whereas those with low growth potential will introduce those with relatively less investment experience. Thus, enterprise growth has a high degree of match with the investment experience of the venture capital institutions.

According to the theory of enterprise property rights, venture capital institutions have formed a community relationship of benefit sharing and risk sharing by making contracts with the founders of enterprises. A high degree of matching between the investment experience of venture capital and the growth of enterprises is conducive to the joint efforts of the founders and venture capital institutions to achieve capital increase and successful listing of enterprises. In other words, if the venture capital institutions have relatively poor investment experience, they will bring less value-added support to the growth of enterprises, which will lead to the phenomenon that enterprises make more efforts and venture capital institutions are lazy; a relatively low growth of enterprises, but with more experience and high industrial reputation of the investment institutions will lead to lazy enterprise founders, both of which are not conducive to the development of the enterprise and the successful listing. Thus, the following hypothesis is made:

H1: With other conditions unchanged, the investment experience of venture capital institutions, industry reputation and the matching degree of enterprise growth are positively related to the possibility of listing.

\subsection{Impact of venture capital and enterprise growth on the listing}

According to the certification and supervision theory, in addition to providing capital financing for enterprises, venture capital institutions also provide more abundant network resources and thus reduce transaction costsfor enterprises. First of all, the more experienced the venture capital institutions introduced in the process of enterprise growth and the higher the industry reputation, the more resources the enterprises will be provided with, from the support of technology, talents and sales channels, to the formulation of enterprise development strategies, analysis of external markets, implementation of internal management systems. From the demands of venture capital institutions, its fundamental purpose is to promote the listing of enterprises and realize capital appreciation and value creation by providing a variety of unique knowledge, experience and other resources to promote the listing of enterprises for them. Secondly, in the case of asymmetric market information, the capital market often defaults that the enterprises screened and invested by venture capital institutions are with development potential and good quality, which is a benign investment signal attracting the attention and favor of potential investors, and provide good qualification certificates for later refinancing or listing. Finally, venture capital institutions have a supervisory role over enterprises. The more experienced a venture capital institution has in practice, the more standardized its

ISSN: 0010-8189 
supervision over the enterprise, and the less mistakes and decision-making deviations it will make in the process of enterprise development. Therefore, in the case of relatively low growth of enterprises, the higher the investment experience and reputation of venture capital institutions, the more conducive to the successful listing of enterprises; In the case of high growth of enterprises, the value-added services provided by venture capital institutions have little influence on the listing of enterprises, and whether they can be listed depends mainly on their own attributes. Thus:

H2: With other conditions unchanged, the investment experience and industry reputation of venture capital institutions are positively related to the listing possibility of enterprises when their growth is low. When the enterprise itself has a high growth potential, the possibility of listing is positively related to the growth of the enterprise, and is not related to the investment experience and industry reputation of the venture capital institutions.

3.3 Impact of the overseas background of venture capital institutions on the listing location of enterprises

Venture capital institutions have a greater effect on enterprises' choice of the IPO market[47]. Firstly, in order to help enterprises to go public smoothly and obtain high quitting returns, venture capital institutions give priority to listing in markets they are familiar with. However, auditing system is adopted for listing in China with strict listing system, complex process and long listing period. The registration system is adopted abroad, with relatively simple process of listing, and a short time. Venture capital institutions, in order to improve their local influence, preferentially recommend enterprises to list in the capital market where they are located. Some venture capitalists with overseas backgrounds will lead to listings on the New York Stock Exchange or the Nasdaq Stock Exchange in order to build a global reputation, thus:

H3: With other conditions unchanged, the overseas background of venture capital institutions is positively related to the listing of enterprises in overseas capital markets.

\section{Sample Selection and Research Design}

\subsection{Samples and data sources}

The data in this paper is based on the sub-databases of "investment events" and "quitting events" given in the "vc/pe investment database" in the wind database, supplemented by "investment events database", "investment quitting event database" and "investment institution data" in the Zdatabase, and at the same time, missing information of some investment institutions with overseas background is collected manually. Since it takes two to three years for a venture capital institution to invest its capital before an enterprise goes public, in this paper, 20102019 was taken as the sample period, and the quitting mode of investment events from 2010 to 2020 was used to determine whether an enterprise is successfully listed, and a total of 46,521 investment events were obtained. On this basis, the number of investment events of each venture capital institution from 2010 to 2019 (the investment of the same venture capital institution in the same enterprise at the same time point is an investment event, and the investment in the same enterprise at two time points is two investment events) and the number of venture capital investments introduced by each enterprise from 2010 to 2020 were counted. After excluding the investment events with missing data and the investment events of real estate projects and film and television dramas, a total of 41,982 investment events were obtained. From 2010 to 2019, a total of 12,057 enterprises received the first round of investment, and the corresponding number of investment events was 19,637. Because the venture capital institutions with only one investment event were not representative[48], these venture capital institutions were excluded, and 1,079 venture capital institutions that received investment and 14,033 investment events corresponding to 6,453 enterprises were obtained, among which 627 venture capital institutions quit from the market.

\subsection{Model setting and variable definition}

In order to test the impact of matching degree between venture capital institutions and enterprises on listing (H1) and the impact of venture capital institutions and enterprise growth on listing (H2), the following regression model is established in this paper:

$$
\begin{aligned}
& \left.\mathrm{IPO}=\alpha_{1}+\alpha_{2} \text { ABS (ENrank }- \text { VCrank }\right)+\alpha_{3} \text { ENrank }+\alpha_{4} \text { VCrank }+\alpha_{5} \text { Period }+\alpha_{6} \text { Capitaltype }+\alpha_{7} \text { Territory } 1 \\
& +\alpha_{8} \text { Territory } 2+\alpha_{9} \text { Territory } 3+\alpha_{10} \text { Industry } 1+\alpha_{11} \text { Industry } 2+\alpha_{12} \text { Industry } 3+\alpha_{13} \text { Industry } 4+\alpha_{14} \text { year }+\varepsilon
\end{aligned}
$$

ISSN: 0010-8189

(C) CONVERTER 2020

Www.converter-magazine.info 
In order to test the impact of overseas background of venture capital on the listing place of enterprises (H3), the following model is established in this paper:

$$
\begin{aligned}
& \text { IPOplace }=\alpha_{1}+\alpha_{2} \text { Capitaltype }+\alpha_{3} \text { Period }+\alpha_{4} \text { Territory } 1+\alpha_{5} \text { Territory } 2+\alpha_{6} \text { Territory } 3 \\
& +\alpha_{7} \text { Industry } 1+\alpha_{8} \text { Industry } 2+\alpha_{9} \text { Industry } 3+\alpha_{10} \text { Industry } 4+\alpha_{11} \text { year }+\varepsilon
\end{aligned}
$$

The main explanatory variables are defined as follows:

4.2.1 Experience in leading investment in venture capital institutions (VCrank)

In this paper, based on the classification method of venture capital institutions[48], the experience of venture capital institutions is expressed as follows. The investment events of 1,079 leading venture capital institutions from 2010 to 2019 were ranked, and the percentage of institutional ranking was taken as the representation of the experience of venture capital institutions, i.e., VCrank= ranking of venture capital institutions/final ranking of all venture capital institutions $* 100$.

\subsubsection{Enterprise growth (ENrank)}

The growth of enterprises is measured by the total number of times of accepting venture capital. The higher the growth of enterprises, the higher the attention of venture capital institutions and the more rounds of venture capital. In this paper, the growth of enterprises was measured by the ranking of the number of investment events introduced by enterprises, and 6,453 enterprises were ranked based on the number of investment events introduced from 2010 to 2019. The percentage of the ranking of enterprises was used as a representation of the growth of enterprises. ENrank= the total round ranking of enterprises attracting venture capital/the final ranking of all enterprises attracting venture capital $* 100$.

4.2.3 Matching degree between venture capital institutions and enterprises (ABS (ENrank-VCrank))

In this paper, the matching degree between venture capital institutions and enterprises was measured by the absolute value of ENrank-VCrank. The lower ABS (ENrank-VCrank) value is, the higher the matching degree between venture capital institutions and enterprises is.

Table 1 stands for symbols and definitions of other explained variables and control variables.

\begin{tabular}{|c|c|c|}
\hline Research contents & Variables & Definitions of variables \\
\hline Listing & IPO & Listed companies are 1 and unlisted companies are 0. \\
\hline Listing place & IPOplace & The overseas listing of enterprises is 1 , and the domestic listing is 0 . \\
\hline $\begin{array}{l}\text { Leading venture } \\
\text { capital institutions }\end{array}$ & VCrank & $\begin{array}{l}\text { VCrank= ranking of venture capital /final ranking of all venture } \\
\text { capital institutions } * 100 . \text { The smaller the VCrank, the higher the } \\
\text { ranking. }\end{array}$ \\
\hline Enterprise growth & ENrank & $\begin{array}{l}\text { ENrank= the total round ranking of enterprises attracting venture } \\
\text { capital/the final ranking of all enterprises attracting venture capital } \\
* 100 . \text { The smaller the ENrank is, the higher the ranking of } \\
\text { enterprise growth is. }\end{array}$ \\
\hline $\begin{array}{l}\text { Matching degree } \\
\text { between venture } \\
\text { capital and enterprise }\end{array}$ & $\begin{array}{l}\text { ABS(ENran } \\
\text { k-VCrank) }\end{array}$ & $\begin{array}{l}\text { ABS (ENrank-VCrank)= the absolute value of (ENrank-VCrank). } \\
\text { The smaller the value of ABS(ENrank-VCrank), the higher the } \\
\text { matching degree between venture capital and enterprise. }\end{array}$ \\
\hline
\end{tabular}

Table 1 Definition of variables 


\begin{tabular}{|c|c|c|}
\hline $\begin{array}{l}\text { Overseas background } \\
\text { of venture capital } \\
\text { institutions }\end{array}$ & Capitaltype & Overseas background is 1 and no overseas background is 0 . \\
\hline $\begin{array}{l}\text { The first round of } \\
\text { venture capital period }\end{array}$ & Period & $\begin{array}{l}\text { The value is } 1 \text { when it is at initial stage and seed stage, and } 0 \text { at } \\
\text { growth stage and mature stage. }\end{array}$ \\
\hline \multirow{3}{*}{$\begin{array}{l}\text { Location of the } \\
\text { enterprise }\end{array}$} & Territory1 & 1 in Beijing-Tianjin-Hebei region, otherwise, 0. \\
\hline & Territory 2 & 1 in Jiangsu, Zhejiang and Shanghai region; otherwise, 0. \\
\hline & Territory3 & 1 in Pearl River Delta region; otherwise, 0. \\
\hline \multirow{4}{*}{$\begin{array}{l}\text { Industry in which the } \\
\text { enterprise is located }\end{array}$} & Industry1 & 1 ininformation technology industry, otherwise, 0. \\
\hline & Industry2 & $\begin{array}{l}1 \text { in communication and computer manufacturing industry, } \\
\text { otherwise, } 0 \text {. }\end{array}$ \\
\hline & Industry3 & 1 intraditional manufacturing industry, otherwise, 0. \\
\hline & Industry4 & 1 inbiomedicalindustry, otherwise, 0. \\
\hline $\begin{array}{l}\text { Year of first round } \\
\text { investment }\end{array}$ & Year & Year of accepting the first round of venture capital. \\
\hline
\end{tabular}

\section{Empirical Results and Analysis}

5.1 Descriptive statistics of samples

Table 2 Descriptive Statistics

\begin{tabular}{llllll}
\hline & No.ofsamples & Min. & Max. & Mean & SD \\
\hline IPO & 6,453 & 0 & 1 & 0.1041 & 0.3055 \\
VCrank & 6,453 & 0.1121 & 100 & 25.08 & 27.3358 \\
ENrank & 6,453 & 0.0311 & 100 & 67.39 & 34.7235 \\
ABS(ENrank & 6,453 & 0.0063 & 99.36 & 43.81 & 28.1605 \\
-VCrank) & & 0 & 1 & 0.4051 & 0.4909 \\
Period & 6,453 & 0 & 1 & 0.2717 & 0.4448 \\
Capitaltype & 6,453 & 0 & 1 & 0.2820 & 0.4500 \\
Territory1 & 6,453 & 0 & 1 & 0.3031 & 0.4564 \\
Territory2 & 6,453 & 0 & 1 & 0.1770 & 0.3817 \\
Territory3 & 6,453 & 0 & 1 & 0.2631 & 0.4404 \\
Industry1 & 6,453 & 0 & 1 & 0.1635 & 0.3698 \\
Industry2 & 6,453 & 0 & 1 & 0.2333 & 0.4230 \\
Industry3 & 6,453 & 0 & 1 & 0.0578 & 0.2334 \\
Industry4 & 6,453 & & &
\end{tabular}

Table 2 shows that the average VCrank, which measures the experience of venture capital institutions, is $25.08 \%$, indicating that most enterprises have rich experience in investment institutions, and the average value for measuring the growth index of enterprises is $67.39 \%$, indicating that most enterprises have weak self-growth ability and few "unicorn" enterprises with development potential, and their growth needs external assistance.

The absolute value of ABS (ENrank-VCrank) is 43.81\%. According to the average values of VCrank and ENrank, there is a big gap in the matching degree between venture capital institutions and invested enterprises, which shows that there are not many enterprises that are really favored by venture capital institutions in the capital market.

The average sum of Territory 1 , Territory 2 and Territory3 is 0.7621 , which indicates that the invested enterprises

ISSN: 0010-8189

(C) CONVERTER 2020

www.converter-magazine.info 
have a high regional concentration and the enterprises supported by venture capital are concentrated in Beijing, Tianjin, Hebei, Jiangsu, Zhejiang, Shanghai and the Pearl River Delta. The average sum of Industry1, Industry2, Industry3 and Industry4 is 0.7177 , which indicates that the invested enterprises also have a high industry concentration, focusing on information technology, communication and computer manufacturing, biomedicine and traditional manufacturing.

5.2 Correlation analysis of samples

Table 3 Correlation Analysis

\begin{tabular}{|c|c|c|c|c|c|c|}
\hline & IPO & VCrank & ENrank & ABS & Period & Capitaltype \\
\hline IPO & 1 & & & & & \\
\hline VCrank & $-0.1355^{* * *}$ & 1 & & & & \\
\hline ENrank & $-0.1742 * * *$ & $0.5428 * * *$ & 1 & & & \\
\hline $\mathrm{ABS}$ & $-0.0863 * * *$ & $-0.2239 * * *$ & $0.6564 * * *$ & 1 & & \\
\hline Period & $-0.2152 * * *$ & 0.0174 & $0.0904 * * *$ & $0.0788 * * *$ & 1 & \\
\hline Capitaltype & $0.0496 * * *$ & $-0.1634 * * *$ & $-0.2457 * * *$ & $-0.1402 * * *$ & $0.0340 * * *$ & 1 \\
\hline
\end{tabular}

Table 3 shows that the experience of venture capital institutions is positively related to the listing of enterprises, and the growth of enterprises is positively related to the listing of enterprises. The higher the matching degree between venture capital institutions and enterprises, the more likely they are to successfully go public. Therefore, $\mathrm{H} 1$ in this paper is verified that when the enterprises receiving the first round of venture capital are in the seed stage or the initial stage, the possibility of the final listing of enterprises is low, and the leading investment institutions with overseas background are more likely to help enterprises to go public.

\subsection{Analysis of regression results}

5.3.1 Impact of matching degree between venture capital institutions and enterprises on listing of enterprises

Table 4 Probit regression results of the matching degree between venture capital institutions and enterprises

\begin{tabular}{|c|c|c|c|c|}
\hline IPO & (1) & (2) & (3) & (4) \\
\hline ABS(ENrank-VCrank) & $\begin{array}{c}-0.00344 * * * \\
(-4.17)\end{array}$ & $\begin{array}{c}-0.00309 * * * \\
(-3.62)\end{array}$ & $\begin{array}{c}-0.00340 * * * \\
(-4.09)\end{array}$ & $\begin{array}{c}-0.00304 * * * \\
(-3.54)\end{array}$ \\
\hline Period & & $\begin{array}{c}-0.93049 * * * \\
(-13.67)\end{array}$ & & $\begin{array}{c}-0.93164 * * * \\
(-13.68)\end{array}$ \\
\hline Capitaltype & & & $\begin{array}{c}0.03011 \\
(0.58)\end{array}$ & $\begin{array}{c}0.04534 \\
(0.84)\end{array}$ \\
\hline Territory 1 & $\begin{array}{c}-0.00575 \\
(-0.08)\end{array}$ & $\begin{array}{c}0.066871 \\
(0.93)\end{array}$ & $\begin{array}{c}-0.01141 \\
(-0.16)\end{array}$ & $\begin{array}{c}0.058418 \\
(0.80)\end{array}$ \\
\hline Territory 2 & $\begin{array}{c}0.094637 \\
(1.51)\end{array}$ & $\begin{array}{c}0.154573 * * * \\
(2.40)\end{array}$ & $\begin{array}{c}0.091525 \\
(1.46)\end{array}$ & $\begin{array}{c}0.150261 * * * \\
(2.32)\end{array}$ \\
\hline Territory3 & $\begin{array}{c}0.436628 * * * \\
(6.54)\end{array}$ & $\begin{array}{c}0.424637 * * * \\
(6.21)\end{array}$ & $\begin{array}{c}0.433677 * * * \\
(6.48)\end{array}$ & $\begin{array}{c}0.420162 * * * \\
(6.13)\end{array}$ \\
\hline Industry1 & $\begin{array}{c}-0.22296 * * * \\
(-3.18)\end{array}$ & $\begin{array}{c}-0.0028 \\
(-0.04)\end{array}$ & $\begin{array}{c}-0.22262 * * * \\
(-3.18)\end{array}$ & $\begin{array}{c}-0.0012 \\
(-0.02)\end{array}$ \\
\hline Industry2 & $\begin{array}{c}-0.13786^{*} \\
(-1.82)\end{array}$ & $\begin{array}{c}0.071015 \\
(0.88)\end{array}$ & $\begin{array}{c}-0.1353^{*} \\
(-1.79)\end{array}$ & $\begin{array}{c}0.07667 \\
(0.94)\end{array}$ \\
\hline Industry3 & $\begin{array}{c}0.28764 * * * \\
(4.92)\end{array}$ & $\begin{array}{c}0.237267 * * * \\
(3.98)\end{array}$ & $\begin{array}{c}0.29227 * * * \\
(4.96)\end{array}$ & $\begin{array}{c}0.244532 * * * \\
(4.05)\end{array}$ \\
\hline
\end{tabular}

ISSN: 0010-8189

(C) CONVERTER 2020 


\begin{tabular}{ccccc} 
Industry4 & $0.284317 * * *$ & $0.293586 * * *$ & $0.285158 * * *$ & $0.294652 * * *$ \\
$\mathrm{~N}$ & $(3.06)$ & $(3.06)$ & $(3.07)$ & $(3.07)$ \\
Adj $\mathrm{R}^{2}$ & 6453 & 6453 & 6453 & 6453 \\
\hline
\end{tabular}

As presented in table 4 above, a total sample size of 6,453 has been collected to verify H1. The results (1) to (4) suggest that regardless of variables Period and Capitaltype, the coefficient of ABS(ENrank-VCrank) is significantly correlated with IPO, which indicates that the closer matching degree between venture capital institutions and enterprises is, the more likelihood of enterprises getting listed will be. In regression (2) and (4), the coefficient of Period is significantly negative, which is consistent with the results in the statistical description, indicating that enterprises usually get listed by first accepting the first round of venture capital in the seed stage or the initial stage, which finally will affect the whole listing process of the enterprise.

\subsubsection{Impact of venture capital institutions' experience and enterprise growth on enterprise listing}

In order to verify $\mathrm{H} 2$, we can see in table 5 that the samples were screened based on the growth of enterprises, and four probit regressions were made to the IPO of enterprises. Regression (1) is the regression of the population sample with a sample size of 6,453 . Regression (2) is to screen out the enterprises with a total round of venture capital investment of 1 and retain the enterprises with a total round of venture capital investment of 2 or more, with a sample size of 3,193. Regression (3) is to screen out the enterprises with total rounds of venture capital of 1 and 2 and retain the enterprises with total rounds of venture capital of 3 or more, with a sample size of 1,644. Regression (4) is to screen out the enterprises with total rounds of venture capital of 1,2 and 3 and retain the enterprises with total rounds of venture capital of 4 or more, with a sample size of 962 .

Table 5 Probit regression results of the impact of venture capital institution experience and enterprise growth

\begin{tabular}{|c|c|c|c|c|}
\hline IPO & (1) & (2) & (3) & (4) \\
\hline VCrank & $\begin{array}{c}-0.00579 * * * \\
(-4.70)\end{array}$ & $\begin{array}{c}-0.00761 * * * \\
(-3.26)\end{array}$ & $\begin{array}{c}-0.00376 \\
(-1.09)\end{array}$ & $\begin{array}{c}-0.00786 \\
(-1.28)\end{array}$ \\
\hline ENrank & $\begin{array}{c}-0.00378 * * * \\
(-4.61)\end{array}$ & $\begin{array}{c}-0.007 * * * \\
(-4.07)\end{array}$ & $\begin{array}{c}-0.01369 * * * \\
(-3.48)\end{array}$ & $\begin{array}{c}-0.02849 * * * \\
(-3.26)\end{array}$ \\
\hline Period & $\begin{array}{c}-0.94146 * * * \\
(-13.52)\end{array}$ & $\begin{array}{c}-0.84463 * * * \\
(-9.86)\end{array}$ & $\begin{array}{c}-0.76499 * * * \\
(-7.20)\end{array}$ & $\begin{array}{c}-0.70968 * * * \\
(-5.51)\end{array}$ \\
\hline Capitaltype & $\begin{array}{c}0.00396 \\
(0.07)\end{array}$ & $\begin{array}{c}0.01468 \\
(0.22)\end{array}$ & $\begin{array}{c}0.0309 \\
(0.36)\end{array}$ & $\begin{array}{c}0.02578 \\
(0.24)\end{array}$ \\
\hline Territory1 & $\begin{array}{c}0.023795 \\
(0.32)\end{array}$ & $\begin{array}{c}0.055126 \\
(0.59)\end{array}$ & $\begin{array}{c}-0.1344 \\
(-1.13)\end{array}$ & $\begin{array}{c}-0.08672 \\
(-0.57)\end{array}$ \\
\hline Territory2 & $\begin{array}{c}0.136328 * \\
(2.08)\end{array}$ & $\begin{array}{c}0.07953 \\
(0.93)\end{array}$ & $\begin{array}{c}-0.09166 \\
(-0.82)\end{array}$ & $\begin{array}{c}-0.07665 \\
(-0.53)\end{array}$ \\
\hline Territory3 & $\begin{array}{c}0.389467 * * * \\
(5.60)\end{array}$ & $\begin{array}{c}0.395303 * * * \\
(4.49)\end{array}$ & $\begin{array}{c}0.214862^{*} \\
(1.85)\end{array}$ & $\begin{array}{c}0.39137 * * \\
(2.58)\end{array}$ \\
\hline Industry1 & $\begin{array}{c}-0.0263 \\
(-0.34)\end{array}$ & $\begin{array}{c}-0.19124 * * \\
(-2.00)\end{array}$ & $\begin{array}{c}-0.11455 \\
(-0.96)\end{array}$ & $\begin{array}{c}-0.14254 \\
(-0.99)\end{array}$ \\
\hline Industry2 & $\begin{array}{c}0.045021 \\
(0.55)\end{array}$ & $\begin{array}{c}-0.10737 \\
(-1.04)\end{array}$ & $\begin{array}{c}-0.08792 \\
(-0.66)\end{array}$ & $\begin{array}{c}-0.16627 \\
(-1.01)\end{array}$ \\
\hline Industry3 & $\begin{array}{c}0.217436^{* * * *} \\
(3.55)\end{array}$ & $\begin{array}{c}0.13643^{*} \\
(1.77)\end{array}$ & $\begin{array}{c}0.137111 \\
(1.34)\end{array}$ & $\begin{array}{c}0.066645 \\
(0.50)\end{array}$ \\
\hline Industry4 & $\begin{array}{c}0.270685^{* * * *} \\
(2.77)\end{array}$ & $\begin{array}{c}0.217981 * \\
(1.73)\end{array}$ & $\begin{array}{c}0.289007 * \\
(1.70)\end{array}$ & $\begin{array}{c}0.155361 \\
(0.66)\end{array}$ \\
\hline $\mathrm{N}$ & 6453 & 3193 & 1644 & 962 \\
\hline $\operatorname{Adj} R^{2}$ & 0.2006 & 0.1707 & 0.1362 & 0.1293 \\
\hline
\end{tabular}

From regression (1) to (4), in essence, the "quality" of enterprises is constantly improving. Regression (1) shows that the coefficients of VCrank and ENrank are significant and negative, that is, the experience of venture capital is positively related to the listing of enterprises, and the richer the investment experience of venture capital

ISSN: 0010-8189 
institutions, the more likely the enterprises are to go public. The growth of an enterprise is positively correlated with its listing, i.e. the higher the growth of the enterprise itself, the more likely the enterprise will be listed. From the total sample, the attributes of venture capital institutions and enterprises will have an impact on the listing of enterprises. In the regression (2), the sample of enterprises with only one venture capital institution is screened out, and the result is similar to that of the regression (1).

In the regressions (3) and (4), the coefficient of VCrank is negative but not significant, while that of ENrank is negative and significant. Compared with the regressions (1) and (2), the coefficient of ENrank increases, indicating that with the improvement of the growth of the enterprise itself, the venture capital institutions have changed from significant influence to no significant influence. The self-growth of an enterprise has a significant impact on IPO, which is more and more significant with the improvement of self-growth. H2 is verified, that is, with other conditions unchanged, when the growth of enterprises is low, the investment experience and industry reputation of venture capital institutions are positively related to the possibility of enterprises' listing; when the growth of enterprises is high, the possibility of listing is positively correlated with the growth of enterprises, but has nothing to do with the investment experience and industry reputation of venture capital institutions.

In addition to verifying the $\mathrm{H} 2$, the coefficients of Territory3 in the four regressions are significant and positive, indicating that the enterprises in the Pearl River Delta region are more likely to go public than those in other regions, regardless of their own growth with other conditions unchanged.

In the regressions (1), (2), (3) and (4), the coefficients of Industry3 and Industry4 gradually change from significant to insignificant, respectively, indicating that with the improvement of the growth of enterprises, the impact of the industrial attributes of traditional manufacturing industry and biological medicine industry on the listing of enterprises is gradually weakened.

In the four regressions, the Period coefficient is significantly negative, which is consistent with the results in the statistical description, indicating that accepting the first round of venture capital in the seed stage or the initial stage is not conducive to the successful listing of the enterprise regardless of the growth of the enterprise, probably because the early introduction of venture capital will disperse the control of the founder of the enterprise, cause disputes over the equity of the enterprise, reduce the production efficiency of the enterprise, and finally affect the listing process of the enterprise.

\subsubsection{Impact of overseas background of venture capital institutions on the listing place of enterprises}

A total of 672 listed companies were selected from the total sample as the sample of $\mathrm{H} 3$ for probit regression. The results are as follows in table 6.

Table 6 Probit regression results of the impact of overseas background of venture capital on the listing place of enterprises

\begin{tabular}{cc}
\hline IPOplace & Result \\
\hline Capitaltype & $1.43243^{* * *}$ \\
& $(11.82)$ \\
Period & 0.00239 \\
Territory1 & $(0.01)$ \\
& $0.435808^{* *}$ \\
Territory2 & $(2.35)$ \\
& 0.136635 \\
Territory3 & $(0.80)$ \\
& $0.305874^{*}$ \\
Industry1 & $(1.84)$ \\
& -0.23534 \\
Industry2 & $(-1.26)$ \\
& $-0.50818^{* * *}$ \\
Industry3 & $(-2.52)$ \\
Industry4 & $-0.69783^{* * *}$ \\
& $(-4.72)$ \\
& $-0.77988^{* * *}$
\end{tabular}

ISSN: 0010-8189 
According to the above table, the coefficient of Capitaltype is significant and negative, that is, venture capital institutions with overseas background will recommend their invested enterprises to be listed in overseas capital markets, which verifies $\mathrm{H} 3$ in this paper, that is, with other conditions unchanged, the overseas background of venture capital institutions is positively correlated with the listing of invested enterprises in overseas markets.

In addition, the coefficients of Territory 1 and Territory 3 are significant and positive, indicating that enterprises in Beijing-Tianjin-Hebei region are more likely to go public overseas. The coefficients of Industry2, Industry3 and Industry4 are all significant and negative, which indicates that enterprises in communication and computer manufacturing industry, traditional manufacturing industry and biomedical industry are more inclined to be listed in China.

\section{Robustness Test}

In order to verify the reliability of the conclusions, the following robustness tests are carried out in this paper.

For $\mathrm{H} 1$ and $\mathrm{H} 2$, the variables used to measure the investment experience of venture capital institutions and the growth of enterprises were replaced, i.e. the investment experience of venture capital institutions was measured by the total number of investment events (VC) of each venture capital institution during the sample period, and the growth of enterprises was measured by the total rounds (EN) of accepting venture capital during the sample period. Because VC has a maximum value of 467 and a minimum value of 2, while EN has a maximum value of 33 and a minimum value of 1 , when calculating $\mathrm{ABS}(\mathrm{EN}-\mathrm{VC})$, the difference between the maximum and minimum values of $\mathrm{EN}$ and $\mathrm{VC}$ is too large, and $\mathrm{ABS}(\mathrm{EN}-\mathrm{VC})$ is inaccurate in measuring the matching degree between venture capital institutions and enterprises. Therefore, natural logarithm (LNVC) is taken for VC, with LNVC having a maximum value of 6.145 and a minimum value of 0.693 , so as to calculate ABS (EN-LNVC), which is shown in table 7.

Table 7 Robustness test results of the impact of matching degree between venture capital institutions and enterprises on their listing

\begin{tabular}{ccccc}
\hline IPO & $(1)$ & $(2)$ & $(3)$ & $(4)$ \\
\hline ABS(EN-LNVC) & $0.05478^{* * *}$ & $0.06787^{* * *}$ & $0.054115^{* * *}$ & $0.067231^{* * *}$ \\
& $(3.89)$ & $(4.63)$ & $(3.84)$ & $(4.59)$ \\
Period & & $-0.95468^{* * *}$ & & $-0.95578 * * *$ \\
& & $(-13.91)$ & & $(-13.91)$ \\
Capitaltype & & & 0.0404 & 0.05135 \\
& & & $(0.78)$ & $(0.95)$ \\
Territory1 & -0.00091 & 0.063064 & -0.00872 & 0.053316 \\
& $(-0.01)$ & $(0.88)$ & $(-0.12)$ & $(0.73)$ \\
Territory2 & 0.087651 & $0.14092^{* *}$ & 0.08352 & $0.136087 * *$ \\
& $(1.40)$ & $(2.18)$ & $(1.33)$ & $(2.10)$ \\
Territory3 & $0.442679 * * *$ & $0.424561 * * *$ & $0.438564 * * *$ & $0.419413 * * *$ \\
& $(6.65)$ & $(6.21)$ & $(6.56)$ & $(6.12)$ \\
Industry1 & $-0.23175^{* * *}$ & -0.00728 & $-0.2312^{* * *}$ & -0.00557 \\
& $(-3.30)$ & $(-0.10)$ & $(-3.29)$ & $(-0.07)$ \\
Industry2 & $-0.16211^{* *}$ & 0.054052 & $-0.15833^{* * *}$ & 0.060648 \\
& $(-2.14)$ & $(0.67)$ & $(-2.09)$ & $(0.74)$ \\
Industry3 & $0.274772^{* * *}$ & $0.226102^{* * *}$ & $0.281225^{* * *}$ & $0.234569^{* * *}$ \\
& $(4.71)$ & $(3.79)$ & $(4.77)$ & $(3.89)$ \\
Industry4 & $0.256782^{* * *}$ & $0.267456^{* * *}$ & $0.258459^{* * *}$ & $0.26919^{* * *}$ \\
& $(2.76)$ & $(2.78)$ & $(2.78)$ & $(2.80)$ \\
$\mathrm{N}$ & 6453 & 6453 & 6453 & 6453
\end{tabular}

ISSN: 0010-8189 

$\operatorname{Adj} R^{2}$
0.1266
0.1823
0.1268
0.1825

According to the above table, the coefficient of ABS (EN-LNVC) is significant and positive, which is the same as $\mathrm{H} 1$; the coefficient of Territory 3 is also significant and positive, which is the same as the hypothesis testing result in this paper. Therefore, the hypothesis test conclusion of $\mathrm{H} 1$ is robust.

In the robustness test of $\mathrm{H} 2, \mathrm{EN}$ and $\mathrm{VC}$ were used to measure the growth of enterprises and the investment experience of venture capital institutions respectively. Samples were screened according to the same method as the hypothesis test in this paper, and probit regression was carried out, and the following regression results in table 8 are obtained.

Table 8 Robustness test results of the impact of venture capital institutions' experience and enterprise growth

\begin{tabular}{|c|c|c|c|c|}
\hline IPO & (1) & (2) & (3) & (4) \\
\hline $\mathrm{VC}$ & $\begin{array}{c}0.000508 * * * \\
(2.46)\end{array}$ & $\begin{array}{c}-4.12 \mathrm{E}-06 \\
(-0.02)\end{array}$ & $\begin{array}{c}-0.00021 \\
(-0.72)\end{array}$ & $\begin{array}{c}\text { 5.17E-05 } \\
(0.14)\end{array}$ \\
\hline $\mathrm{EN}$ & $\begin{array}{c}0.073594 * * * \\
(7.07)\end{array}$ & $\begin{array}{c}0.060001 * * * \\
(5.16)\end{array}$ & $\begin{array}{c}0.057059 * * * \\
(4.14)\end{array}$ & $\begin{array}{c}0.050568 * * * \\
(3.17)\end{array}$ \\
\hline Period & $\begin{array}{c}-0.96478 * * * \\
(-13.75)\end{array}$ & $\begin{array}{c}-0.85683 * * * \\
(-9.93)\end{array}$ & $\begin{array}{c}-0.77822 * * * \\
(-7.27)\end{array}$ & $\begin{array}{c}-0.71163 * * * \\
(-5.51)\end{array}$ \\
\hline Capitaltype & $\begin{array}{c}0.00658 \\
(0.12)\end{array}$ & $\begin{array}{c}0.01193 \\
(0.18)\end{array}$ & $\begin{array}{l}0.022 \\
(0.25)\end{array}$ & $\begin{array}{c}0.03088 \\
(0.28)\end{array}$ \\
\hline Territory1 & $\begin{array}{c}0.029136 \\
(0.40)\end{array}$ & $\begin{array}{c}0.055669 \\
(0.60)\end{array}$ & $\begin{array}{c}-0.13748 \\
(-1.15)\end{array}$ & $\begin{array}{c}-0.09204 \\
(-0.61)\end{array}$ \\
\hline Territory 2 & $\begin{array}{c}0.137034^{* *} \\
(2.10)\end{array}$ & $\begin{array}{c}0.076368 \\
(0.89)\end{array}$ & $\begin{array}{c}-0.10477 \\
(-0.94)\end{array}$ & $\begin{array}{r}-0.0981 \\
(-0.67)\end{array}$ \\
\hline Territory3 & $\begin{array}{c}0.404802 * * * \\
(5.85)\end{array}$ & $\begin{array}{c}0.408421 * * * \\
(4.65)\end{array}$ & $\begin{array}{c}0.230591 * * \\
(1.99)\end{array}$ & $\begin{array}{c}0.387235 * * * \\
(2.56)\end{array}$ \\
\hline Industry1 & $\begin{array}{c}-0.04365 \\
(-0.57)\end{array}$ & $\begin{array}{c}-0.18429 * \\
(-1.93)\end{array}$ & $\begin{array}{c}-0.1056 \\
(-0.88)\end{array}$ & $\begin{array}{c}-0.13082 \\
(-0.91)\end{array}$ \\
\hline Industry2 & $\begin{array}{c}0.037555 \\
(0.46)\end{array}$ & $\begin{array}{c}-0.1035 \\
(-1.00)\end{array}$ & $\begin{array}{c}-0.08992 \\
(-0.68)\end{array}$ & $\begin{array}{c}-0.15576 \\
(-0.95)\end{array}$ \\
\hline Industry3 & $\begin{array}{c}0.234567 * * * \\
(3.86)\end{array}$ & $\begin{array}{c}0.141972 * \\
\quad(1.85)\end{array}$ & $\begin{array}{c}0.131924 \\
(1.30)\end{array}$ & $\begin{array}{c}0.061903 \\
(0.47)\end{array}$ \\
\hline Industry4 & $\begin{array}{c}0.27478 * * * \\
(2.84)\end{array}$ & $\begin{array}{l}0.211251^{*} \\
\quad(1.69)\end{array}$ & $\begin{array}{c}0.272855 \\
\quad(1.61)\end{array}$ & $\begin{array}{c}0.175512 \\
(0.75)\end{array}$ \\
\hline $\mathrm{N}$ & 6453 & 3193 & 1644 & 962 \\
\hline $\operatorname{Adj} R^{2}$ & 0.1955 & 0.1677 & 0.1369 & 0.1252 \\
\hline
\end{tabular}

According to the above table, the coefficient of $\mathrm{VC}$, the proxy variable of venture capital institutions, is significant and positive in regression (1), but not significant in regressions (2), (3) and (4), which is consistent with the H2, that is, the possibility of listing is positively correlated with the growth of enterprises, and with the improvement of the growth of enterprises, the impact of venture capital institutions on listing decreases. The coefficients of EN are significant and positive in the regressions (1), (2), (3) and (4), thus H2 holds.

In the robustness test, the Territory3 coefficients are significant and positive in the four regressions, and the conclusion is the same as that in the original hypothesis test. The significance of coefficients of Industry 3 and Industry4 decreases gradually in the regressions from (1) to (4), and the conclusion is the same as that in the original hypothesis test. The coefficient of Period is significantly negative, which is the same as the result of the original hypothesis test. Therefore, the hypothesis test conclusion of $\mathrm{H} 2$ appears robust.

In the robustness test of $\mathrm{H} 3$, the regression method was replaced and logit regression was performed on the samples in $\mathrm{H} 3$, and the results are as follows in table 9. 
Table 9 Robustness test results of the impact of overseas background of venture capital institutions on the listing place of enterprises

\begin{tabular}{cc}
\hline IPOplace & Result \\
\hline Capitaltype & $2.40911^{* * *}$ \\
& $(11.47)$ \\
Period & -0.01403 \\
& $(-0.04)$ \\
Territory1 & $0.754252^{* *}$ \\
& $(2.30)$ \\
Territory2 & 0.235714 \\
& $(0.77)$ \\
Territory3 & $0.537059^{*}$ \\
& $(1.81)$ \\
Industry1 & -0.38913 \\
& $(-1.20)$ \\
Industry2 & $-0.86374^{* *}$ \\
Industry3 & $(-2.47)$ \\
& $-1.22128^{* * *}$ \\
Industry4 & $(-4.70)$ \\
$\mathrm{N}$ & $-1.40615^{* * *}$ \\
Adj $\mathrm{R}^{2}$ & $(-3.33)$ \\
& 672 \\
\end{tabular}

According to the above table, the Capitaltype coefficient is significant and negative, the Territory 1 and Territory 3 coefficients are significant and positive, and the Industry2, Industry3 and Industry4 coefficients are significant and negative. This conclusion is consistent with the test result of $\mathrm{H} 3$, so the conclusion of $\mathrm{H} 3$ is robust.

\section{Research Conclusions and Suggestions}

In this paper, the event of IPO is studied to emphatically analyze how venture capital influences on the process of enterprises' listing. Firstly, it discusses how to choose between venture capital institutions and high-tech enterprises from the theoretical level, and discusses the impact of the degree of matching on the basis of measuring internal growth of enterprises and the characteristics of venture capital. Result shows that the higher the degree of matching between venture capital institutions and enterprises, the easier it is for enterprises to go public. Secondly, the roles of venture capital and the growth of enterprises themselves in the listing of enterprises are studied. The research results show that both investment experience of venture capital and the growth of enterprises themselves will have a significant positive impact on the listing of enterprises. The richer the investment experience of venture capital institutions and the higher the growth of enterprises themselves, the easier it is for enterprises to go public. In case of a low growth of enterprises, venture capital's background and expertise has a significant impact on the listing of enterprises. With the improvement of the growth of the enterprises themselves, venture capital's factors gradually become insignificant and enterprises canincrease the possibility of achieving the capital value-adding themselves. Finally, the impact of overseas background of venture capital institutions on the listing location of enterprises is analyzed. The results show that venture capital institutions with overseas background are more likely to promote the listing of invested enterprises in the overseas capital market.

Based on the empirical findings, we have implications for entrepreneurship research and practice as well as suggestions from two aspects: venture capital institutions and start-up enterprises:

1. For venture capital institutions: First, a detailed pre-investment investigation of policies and due diligence in industries should be conducted before making investment decisions. In the case of unrestricted investment projects, venture capital institutions should invest in prospective, growing or mature enterprises to realize capital hedging and proliferating. Second, highly matched businesses should be chosen to invest. In the case of limited investment projects, enterprises with high matching degree with venture capital institutions should be selected for investment as far as possible in order to improve the initiative of enterprises and venture capital institutions, and increase the opportunity for enterprises to ultimately go public successfully. Third, the investment experience of the investment

ISSN: 0010-8189

(C) CONVERTER 2020

www.converter-magazine.info 
institutions themselves should be enriched, because it can not only provide value-added services for enterprises better, but also expand the project selection space for venture capital in the future. Enterprises with a high growth potential will give priority to experienced venture capital institutions so that they have more initiative and voice under the premise of two-way selection between enterprises and venture capital institutions. Fourth, expand the positive influence of the investment on the enterprise as much as possible, and help the enterprise to break through its own limitations and grow rapidly. When the growth of enterprises is not high, venture capital has a significant impact on the final listing of enterprises.

2. For enterprises: First, the growth of the enterprises themselves should be improved. The growth of the enterprises themselves is the determining factor for them to go public, which can be effectively improved by improving enterprise management, improving corporate profitability, increasing investment in research and development and other measures. At the same time, the higher the growth of enterprises, the greater the room for choosing venture capital. Second, seeking the support of venture capital should depend on its own actual development. The venture capital institution suitable for the future IPO planning should be selected according to the development stage of the enterprises. Third, venture capital institutions with overseas background should be selected if the enterprises have the expectation of listing overseas.

\section{Acknowledgements}

This research is the periodical achievement of the Humanities and Social Sciences Project (" Regulatory Science and Technology + National Governance ": the Fusion Mechanism and Realization Path of Accounting Supervision) of the Ministry of Education and the Natural Science Foundation of Shandong Province (Research on China's Government Accounting Supervision Index and Governance System ZR2017MG025).

\section{References}

[1] X.R. Zhang, R. Shen, J.Y. Lu, "Venture Capital Research: Overview and Prospects,"Foreign Economics and Management, vol. 41, no. 4, pp. 58-70, 2019.

[2] C. Yu, Z.P. Fan, “Approaches to venture capital project selection considering decision-makers' regret avoidance," Chinese Journal of Management Science, vol.24, no. 6, pp. 29-37, 2016.

[3] H. Chen, P. Gompers,A.Kovner, J.Lerner, "Buy local? The geography of venture capital,"Journal of Urban Economics, vol. 67, no. 1, pp. 90-102, 2010.

[4] K.R. Conner, C.K.Prahalad, "A resource-based theory of the firm: Knowledge versusopportunism,”Organization Science, pp. 477-501, 1996.

[5] D.Cumming, "Venture capital: Investment strategies, structures, and policies," Hoboken, NJ: John Wiley \& Sons, Inc, 2010.

[6] Y.H. Li, "Research on the method of venture capital project selection based on similar case analysis," Management Review, vol. 29, no. 8, pp. 65-76, 2017.

[7] C.Y. Liu, Q. Duan, "Process of venture capital evaluation and decision making," Chinese and Foreign Science and Technology Policy and Management, vol. 12, pp. 64-74, 1996.

[8] L.Q. Yao, J.J. Shao, "Research on Options Model of Stage Venture Capital Value Evaluation," Finance and Accounting Bulletin, vol. 11, pp. 29-32, 2007.

[9] D.D.Clercq, D. Dimov, "Internal knowledge development and external knowledge access in venture capital investment performance,” Journal of Management Studies, vol.45, no. 3, pp. 585-612, 2008.

[10] A.K. Jiang, "Research on Risk Prediction and Governance of Private Equity Investment," Beijing Jiaotong University,2018.

[11] S.C. Liao, "Quality of managers in venture capital project evaluation,"Journal of Management Science, vol.03, pp. 42-45, 2002.

[12] C. Ding, L. Chen, "Venture Capital Incentive Mechanism Based on Equitable Preference of Venture Entrepreneurs: From the Perspective of Explicit and Implicit Efforts,'Journal of Management Science, vol. 19, no. 4, pp. 104-117, 2016.

[13] Y. Lu, Y.Q. Zhang, R. Jia, J.H. Li, "Syndicate" venture capital and firm innovation," Financial Research, vol. 6, pp. 159-175, 2017. 
[14] T.Hellman, "The Interaction between Product Market and Financing Strategy: The Role of Venture Capital,” Review of Financial Studies, vol. 13, no. 4, pp. 959-984, 2000.

[15] F.M. Song, T.T. Chen, "Research on evaluation index system of high-tech investment project," China Soft Science, vol. 1, pp. 90-94, 1999.

[16] D. Engel, M.Keilbach,"Firm-level implications of early stage venture capital investment: An empirical investigation," Journal of Empirical Finance, vol.14, no.2, pp. 150-167, 2007.

[17] G.Piacentino,"Venture Capital and Capital Allocation," The Journal of Finance, vol. 74, no. 3, pp. 1261-1314, 2019.

[18] D.B. Audretsch, E.E. Lehmann,"Financing High-Tech Growth: The Role of Banks and Venture Capitalists,"Schmalenbach Business Review, vol. 56, no. 4, pp. 340-357,2004.

[19] L.F. Hu, Z.J. Zhou, "Can Venture Capital Institutional Shareholding Ease Subsequent Financing Constraints?” Journal of Economic Management, vol. 40, no. 7, pp. 91-109, 2018.

[20] K.G. Zhou, Y.Z. Lu, "Financial structure and national innovation: Evidence from OECD countrie," International Finance Studies, vol. 03, pp. 24-33, 2019.

[21] C.P. Wu, S.N. Wu, J.Y. Cheng, L. Wang, "An empirical study on the impact of venture capital on the investment and financing behavior of listed companies,” Economic Research Journal, vol.47, no. 01, pp. 105-119, 2012.

[22] W.L. Megginson,K.A. Weiss, "Venture Capitalist Certification in Initial Public Offerings,” The Journal of Finance, vol.46, no.3, pp. 879-903, 1991.

[23] Y. Li, X.J. Wang, "The certification effect and market power of venture capital in China's Growth Enterprise Market,” Journal of Finance and Economics, vol. 41, no. 02, pp. 4-14, 2015.

[24] H.K. Chen, "Research on principal-agent risk and its governance mechanism in venture capital,’Journal of Management Science, vol. 01, pp. 114-116, 2006.

[25] C.B. Barry, C.J. Muscarella, J.W. Peavy, et al., "The Role of Venture Capital in the Creation of Public Companies: Evidence from the Going-Public Process,” Journal of Financial Economics, vol. 27, no. 2, pp. 447-471, 1990.

[26] Z.Z. Feng, T. Cao, J. Wen, "Heterogeneous venture capital, joint shareholding and IPO underpricing,"Journal of Zhongnan University of Economics and Law, vol.02, pp. 57-67, 2016.

[27] D.J. Cumming, J.G. Macintosh,"Venture capital investment duration in Canada and the United States," Journal of Multinational Financial Management, vol.11, no.4, pp. 445-463, 2001.

[28] G. Lee, R.W. Masulis, “Do more reputable financial institutions reduce earnings management by IPO issuers,” Journal of Corporate Finance, vol.17, no. 4, pp. 982-1000, 2011.

[29] O. Brunninge, M. Nordqvist, “Ownership structure, board composition and entrepreneurship: Evidence from family firms and venture-capital-backed firms,'International Journal of Entrepreneurial Behavior and Research, vol.10, pp. 85-105, 2015.

[30] Y. Long, S.D. Pang, H. Zhang, "Research on the influence of post-investment management of venture capital on the governance structure of high-tech enterprises," Science of Science and Management of Science and Technology, vol.31, no. 09, pp. 158-162, 2010.

[31] H.J. Sapienza, A.K. Gupta, "Impact of Agency Risk and Task Uncertainty on Venture Capitalist-CEO Interaction,” The Academy of Management Journal, vol.37, no. 6, pp. 1618-1632, 1994.

[32] S.N. Kaplan, P. Stromberg, "Financial Contracting Theory Meets the Real Word: An Empirical Analysis of Venture Capital Contracts," The Review of Economic Studies, vol. 70, no.2, pp. 281-315, 2003.

[33] R. Inderst, H.M.Mueller,"Early-stage financing and firm growth in new industries," Journal of Financial Economics, vol. 93, no. 2, pp. 276-291, 2009.

[34] Y.V. Hochberg, A. Ljungqvist,Y. Lu, "Whom You Know Matters: Venture Capital Networks and Investment Performance,” Journal of Finance, vol. 62, no. 1,pp. 251-301, 2007.

[35] S. Kortum, J. Lerner, “Assessing the Contribution of Venture Capital to Innovation,” Rand Journal of Economics, pp. 674-692, 2000.

[36] Y. Long, P.P. Shi, “The Impact of Venture Capital on the Technological Innovation Effect of High-tech Firms," Economics and Management Research, vol. 07, pp. 38-44, 2012.

ISSN: 0010-8189 
[37] Y.N. Gou, J. Dong, "The impact of venture capital background on firm technological innovation," Science Research Management, vol. 35, no. 02, pp. 35-42, 2014.

[38] X.Y. Chen, X.F. Hui,"Venture Capital and the Growth of Invested Enterprises -- Empirical Evidence from China's Growth Enterprise Market," Journal of Xi 'anJiaotong University (Social Science Edition), vol. 34, no. 03, pp. 25-32, 2014.

[39] G.K. Wang, T. Zhang, M. Hong, "Research on the promotion effect of private equity investment on enterprise growth,” Modern Management Science, vol. 07,pp. 18-20, 2017.

[40] D.C. Wen, N.J. Ye,Z.M. Fan,"Research on the IPO effect of small and medium-sized enterprises from the perspective of venture capital," Zhejiang Social Sciences, vol.11, pp. 40-46, 2010.

[41] P.P. Qiu, "Impact of venture capital on IPO performance of GEM companies," Journal of Finance and Accounting, vol. 12, pp. 34-38, 2013.

[42] J.L. Chen, "The impact of venture capital on the performance growth of China's GEM companies," Science of Finance and Economics, vol. 3, pp. 50-58, 2012.

[43] H.B. Fan, "The determinants of venture capital investment performance in China," Management of Scientific Research, vol. 33, no. 03, pp. 128-135, 2012.

[44] L.L. Tang, Y. Tan, "Research on the joint investment performance of venture capital institutions in China: An empirical study from China's IPO market,” Journal of Fudan University (Natural Science), vol. 54, no. 03, pp. 336-342, 2015.

[45] R. Lungeanu, E.J. Zajac, "Venture Capital Ownership as a Contingent Resource:How Owner-firm Fit Influences IPO Outcomes," Academy of Management Journal, vol. 59, no. 3, pp. 930-955, 2016.

[46] C. Wei, J. Hu, C.H. Yang, "Study on the influence of venture capital characteristics on IPO process,"Journal of Hefei University of Technology (Social Science Edition), vol. 02, pp. 18-26, 2021.

[47] H. Xu, F.F. Yu, "Heterogeneity of venture capital background and exit timing: An empirical study based on trust perspective," Journal of Nanjing Audit University, ol 6, pp. 58-68, 2020.

[48] H. Fu, Z.F. Zhao, "Do Start-up Enterprises IPO by themselves or by "venture capital"?" Journal of Economic Research, vol. 05, pp. 132-146, 2017. 